\title{
Bone Deformities in Healthy Children Secondary to Hypovitaminosis D
}

\author{
Drali Ouardia*, Berrah Hassina \\ Department of Pediatrics B. Hospital centre university of Hussein Dey. Algiers
}

*Corresponding author: Drali Ouardia, Department of Pediatrics B. Hospital centre university of Hussein Dey. Algiers

Received date: 14 February, 2022 I Accepted date: 24 February, 2022 | Published date: 28 February, 2022

Citation: Drali O, Hassina B. (2022) Bone Deformities in Healthy Children Secondary to Hypovitaminosis D. J Orthop Pract 2(1): doi https://doi.org/10.54289/JOP2200102

Copyright: () 2022 Drali O. This is an open-access article distributed under the terms of the Creative Commons Attribution License, which permits unrestricted use, distribution, and reproduction in any medium, provided the original author and source are credited.

\section{Summary}

Vitamin D has been known for nearly a century for its antirachitic action. Hypovitaminosis D at the child leads to a defect in bone mineralization related to an alteration of phosphocalcic homeostasis resulting in a disturbance of growth. The best treatment is prevention, which must be systematic. We propose, through this case-control study, to determine the vitamin $\mathrm{D}$ and PTH status of healthy infants with bone deformities of the lower limbs and to identify the risk factors. The inclusion of healthy infants was done chronologically and consecutively for all months of the year. The duration of the study was two years, from January 1,2014 to December 31, 2016.

Results: The analysis focuses on 395 infants aged between 9 and 24 months recruited during the 4 seasons divided into 2 groups: those with deformities of the lower limbs (23 cases) mainly represented by genes varum and knees valve and a control group (272 cases). Children with bone deformities had lower vitamin D levels than children without bone deformities $(9 \pm 1 \mathrm{ng} / \mathrm{ml}$ vs $20 \pm 8 \mathrm{ng} / \mathrm{ml})(\mathrm{p}=0.0001)$. PTH levels were higher in children with bone deformities than in those without bone deformities $(73 \pm 11 \mathrm{pg} / \mathrm{ml}$ vs $31 \pm 14 \mathrm{pg} / \mathrm{ml})(\mathrm{P}=0.001)$. The prevalence of vitamin $\mathrm{D}$ deficiency was higher in children with bone deformities who were: overweight or obese $(p=0.001)$. Brown or matte phototype $(p=0.001)$. Sun exposure less than 15 minutes $(\mathrm{p}=0.001)$. Bad living conditions $(\mathrm{p}=0.02)$. Low dietary intake of vitamin $\mathrm{D}(\mathrm{p}=0.001)$. Low calcium intake $(\mathrm{p}=0.001)$

Conclusion: The clinical screening of vitamin D deficiency in search of bone deformities should be evoked more easily by the medical profession, especially since the confirmation of the diagnosis is easy and supplementation is simple, inexpensive and well tolerated.

Keywords: Vitamin D, PTH, bone deformities, child, Algeria

\section{Introduction}

Vitamin D has been known for nearly a century for its antirachitic action. It is on this basis that the needs and recommended intakes have been defined, as proposed until now in order to prevent the occurrence of a bone mineralization defect. Hypovitaminosis D in children leads to a defect in bone mineralization related to an alteration of phosphocalcic homeostasis resulting in a disturbance of growth. Deformities of the spine vertebral (scoliosis), legs (Varus or valgus of the knees) and a delay in the age of walking compared to a child of the same age can be observed realizing in some cases the complete picture of rickets. 
Vitamin D deficiency is a major public health problem in developed and developing countries; worldwide it is estimated that one billion people have such a deficit [1-3].

\section{Method}

Our study is a cross-sectional, case-control, prospective, descriptive, analytical and unicentric study. The inclusion of healthy infants was done chronologically and consecutively during all the months of the year. The duration of the study was 2 years, from January 1, 2014, to December 31, 2016 conducted during the 4 seasons.

The sample was constituted according to a random survey by drawing lots by simple numbering (statistical method validated by the WHO) after having obtained the written and signed consent of the parents.

We have included the

- $\quad$ Healthy infants aged 9 to 24 months.

- Vitamin D received at 1 and 6 months according to the national scheme (after checking the health record).

- Free of any chronic or acute pathology that may interfere with the metabolism of vitamin D (Skin, digestive, hepatic, parathyroid and renal pathology, etc.).

- Not receiving any treatment with vitamin D or calcium in the 3 months preceding inclusion.

- Not receiving any treatment that may interfere with vitamin D metabolism or calcium phosphate metabolism: Anticonvulsants, corticosteroids, rifampicin.

An information sheet was drawn up comprising several items. This questionnaire made it possible to provide information on age, sex, height and weight measurements and skin pigmentation according to a color chart (international classification of Fitzpatrick). For the dietary survey, the parents of the infants had to answer an exhaustive questionnaire concerning their child's vitamin D intake: frequency, type and quantity of food consumed during the week preceding the survey.

The determination of total $250 H D$ was carried out on serum after centrifugation by the VIDAS BioMérieux analyzer which allows the immunoenzymatic determination of 25OHD by ELFA technique (Enzyme Linked fluorescent Assay). The vitamin D standards used for the evaluation of our results are those accepted by the majority of authors, set by the American Society of Endocrinology and the GRIO [6] (Standards applied by our laboratory). The PTH assay was performed by the Cobas e411 Roche diagnostic analyzer. The biochemistry unit carries out daily internal quality control before any validation of the results. The acceptable coefficients of variation in the laboratory are less than $3 \%$ of the recommended target regardless of the measured parameter.

SPSS 22 software was used for the statistical analysis. The significance level of the statistical tests and the simple and multiple logistic regression is $\mathrm{p}<0.05$.

\section{Results}

Among the 395 children collected, 23 had bone abnormalities, i.e., 5.8\%. Bone deformities were essentially represented by genes varum and knees valgus. We did not find in our study population the other bone deformities described in the literature, namely: epiphyseal swellings, thorax breastbone, scoliosis or fractures.
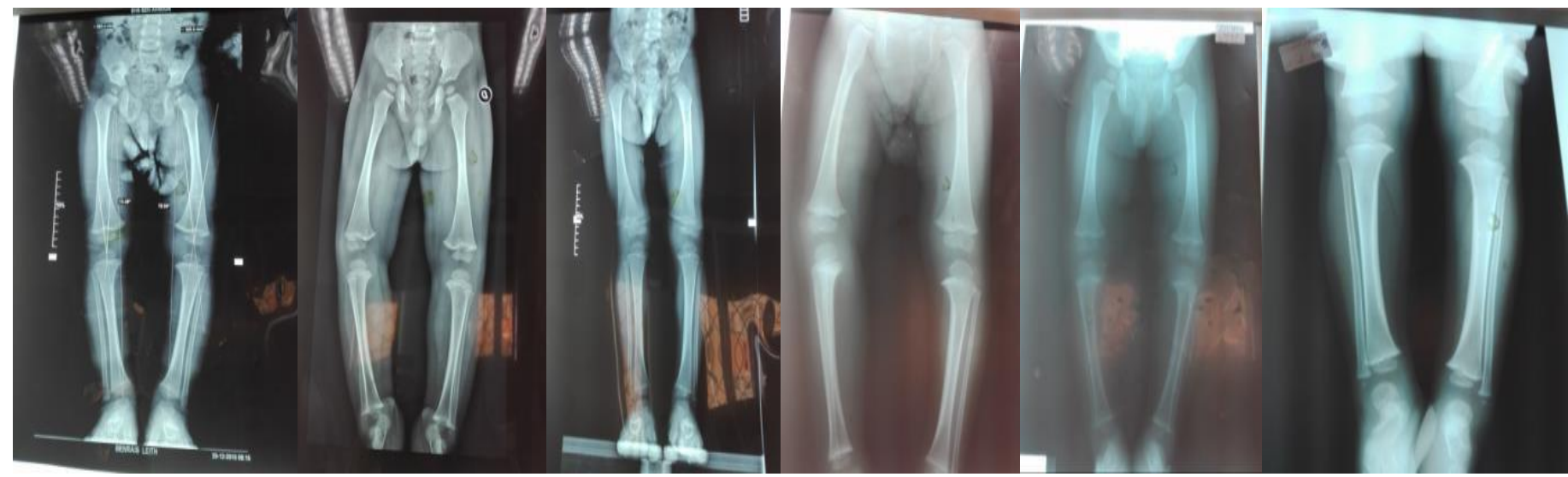

Figure 1: X-ray of the lower limbs showing bone deformities 
It is observed that children with bone deformities accumulated all the risk factors for hypovitaminosis D compared to children without bone deformities. Children with bone deformities had lower vitamin D levels than children without bone deformities $(9 \pm 1 \mathrm{ng} / \mathrm{ml}$ vs $20 \pm 8 \mathrm{ng}$ /ml) $(\mathrm{p}=0.0001)$. PTH levels were higher in children with bone deformities than in those without bone deformities (73 $\pm 11 \mathrm{pg} / \mathrm{ml}$ vs $31 \pm 14 \mathrm{pg} / \mathrm{ml})(\mathrm{P}=0.001)$. Table 1 represents the distribution of children according to the presence or absence of bone deformities

\begin{tabular}{|c|c|c|c|c|c|}
\hline Bone deformities & YES: 23 & $5.8 \%$ & NO :272 & $94.2 \%$ & $\mathbf{P}$ \\
\hline Sex & 14 & $61 \%$ & 467 & $53 \%$ & $\mathrm{P}=0.05$ \\
\hline Girls & & & & 1707 & \\
\hline \multicolumn{6}{|l|}{ Boys } \\
\hline Mean age \pm SD & $24 \pm 8$ & & $37 \pm 10$ & & $\mathrm{P}=0.01$ \\
\hline BMI & $22 \pm 3$ & & $18.5 \pm 2.5$ & & $P=0.05$ \\
\hline regular weight & 8 & $35 \%$ & 971 & $98 \%$ & $\mathrm{P}=0.01$ \\
\hline Overweight & 10 & $43.5 \%$ & 15 & $1.5 \%$ & $\mathrm{P}=0.001$ \\
\hline Obesity & 5 & $22 \%$ & 7 & $1 \%$ & $P=0.001$ \\
\hline Phototype & 6 & $26 \%$ & 433 & $44 \%$ & $\mathrm{P}=0.01$ \\
\hline Light & 7 & $30.5 \%$ & 331 & $33 \%$ & $P=0.01$ \\
\hline Mast & 10 & $43.5 \%$ & 224 & $23 \%$ & $P-0001$ \\
\hline \multicolumn{6}{|l|}{ Brown or black } \\
\hline Sun exposure & 17 & $70 \%$ & 501 & $50.5 \%$ & $\mathrm{P}=0.001$ \\
\hline Less than 15 minutes & 5 & $17 \%$ & 341 & $34 \%$ & $\mathrm{P}=0.01$ \\
\hline 15-30 minutes & 1 & $13 \%$ & 151 & $15 \%$ & $\mathrm{P}=0.1$ \\
\hline \multicolumn{6}{|l|}{ More than 30 minutes } \\
\hline \multirow{2}{*}{$\begin{array}{l}\text { CSE } \\
\text { Favourable }\end{array}$} & 11 & $48 \%$ & 153 & $15 \%$ & $P=0.001$ \\
\hline & 9 & $39 \%$ & 704 & $81 \%$ & $P=0.001$ \\
\hline Averages & 3 & $13 \%$ & 136 & $4 \%$ & $\mathrm{P}=0.02$ \\
\hline \multicolumn{6}{|l|}{ Unfavourable } \\
\hline Dietary intakes of vitamin D & 95 IU/day & & $170 \mathrm{IU} /$ day & & $\mathrm{P}=0.001$ \\
\hline Calcium intake & $130 \mathrm{mg} /$ day & & $202 \mathrm{mg} /$ day & & $\mathrm{P}=0.001$ \\
\hline Mean Rate $250 H D \pm$ SD $(\mathrm{ng} / \mathrm{ml})$ & $9 \pm 1$ & & $20 \pm 8$ & & $\mathrm{P}=0.0001$ \\
\hline 25OHD deficiency $(\%)$ & 23 & $100 \%$ & 576 & $58 \%$ & $\mathrm{P}=0.0001$ \\
\hline Mean PTH level \pm SD $(\mathrm{pg} / \mathrm{ml})$ & $73 \pm 11$ & & $31 \pm 14$ & & $\mathrm{P}=0.001$ \\
\hline
\end{tabular}

The prevalence of vitamin D deficiency was higher in children with bone deformities who were: overweight or obese $(\mathrm{p}=0.001)$. Brown or matte phototype $(\mathrm{p}=0.001)$. Sun exposure less than 15 minutes $(\mathrm{p}=0.001)$. Bad living conditions $(\mathrm{p}=0.02)$. Low dietary intake of vitamin $\mathrm{D}(\mathrm{p}=0.001)$. Low calcium intake $(\mathrm{p}=0.001)$.

\section{Discussion}

In our work, bone deformities affected $5.8 \%$ of children $(23$ children). These were mainly knee-type lower limb deformities. varum or valgum. Our rate was lower than those observed in the Djennane study (16.5\%) [4].

We have objectified low plasma concentrations of 25OHD
(Less than $10 \mathrm{ng} / \mathrm{ml}$ ) and an increase in PTH in children with bone deformities suggesting a certain degree of bone mineralization disorder. In addition, these children had several potential factors for hypovitaminosis D (dark phototype, low sun exposure, low dietary intake of vitamin D, etc.) compared to those without deformities. correction of 
hypovitaminosis D and follow -up in pediatric surgery.

During the sixties, deficiency rickets was an important cause of morbidity and mortality in Algeria, in particular because of its respiratory complications. National surveys carried out by WHO experts (Raoult in 1963 then Léveque in 1965) had shown that it was observed more than once in three in children under 3 years of age [5]. In 1973, Si Ahmed [6] found a radiological incidence of $33 \%$ in the age group of 3 to 23 months. A year later, in a city of Bouzareah, the systematic study of all infants of the same age group made by Chouakri [7] showed an incidence of $49 \%$.

The prevalence of vitamin D deficiency was higher in children with bone deformities who were: overweight or obese ( $\mathrm{p}=$ $0.001)$. Brown or matte phototype $(p=0.001)$. Sun exposure less than 15 minutes $(\mathrm{p}=0.001)$. Bad living conditions $(\mathrm{p}=0.02)$. Low dietary intake of vitamin $\mathrm{D}(\mathrm{p}=0.001)$. Low calcium intake $(\mathrm{p}=0.001)$.

Prevention strategies against deficiency rickets vary from country to country depending on the climate and the socioeconomic and cultural context. In Algeria, rickets has practically disappeared from paediatric pathology since the 1980s, in particular due to the fact of having systematically supplemented all infants with vitamin D. Indeed, since independence, a prevention strategy has been adopted. which sets at the age of 1 month and 6 months the systematic intake of a dose of 200,000 IU of vitamin D orally. Although the strategy currently followed seems satisfactory, insofar as we observe practically no more deficiency rickets in our country, a certain number of questions remain posed with regard to this strategy. A first question concerns children of preschool age and adolescents who maintain a high growth velocity and who are not supplemented during this essential period of their development. A second question concerns the number and the doses necessary to administer to reach the optimal level of vitamin $\mathrm{D}$ in order to have good bone growth.

Vitamin D deficiency leads to dysregulation of calcium and phosphate levels. Histologically, osteoblasts produce osteoid tissue which accumulates without calcifying. The multiplication of cartilaginous cells in the maturation zone and their non-involution, due to the lack of ossification, lead to an increase in the thickness of the growth plate and its spreading in width in the absence of a rigid structure. The clinical translation is the palpable widening of the extremities of the long bones and ribs and the loss of rigidity of the bones which deform under the effect of the weight of the body and muscular tractions. The first clinical signs appear from the second month [8-10]. Lower limb deformities attributed to vitamin D deficiency have mainly been observed in Africa, Asia and the Middle East. Its prevalence is considered to be lower in children of Caucasian origin [11]. Bone deformities may be present for several years before the diagnosis of hypovitaminosis D is considered. Indeed, Plotnikoff in 2003 demonstrated that between the first symptom and the diagnosis, it took between 7 and 103 months with an average of $59.2 \pm 36.2$ months [12].

It is now established that an optimal vitamin D status plays an essential role in the constitution of an optimal bone mass during childhood and by the same in the prevention of osteoporosis in adulthood.

\section{Conclusion}

The evaluation of the protocols prescribed until now is necessary to know if they allow a normalization of vitamin D levels. Indeed, the recommendations dating from the 90s are old and totally oriented towards the prevention of rickets which has almost disappeared in our country. There remains an omnipresent concern for optimizing the $25 \mathrm{OHD}$ status and the mineralization and bone structure. The results could be very interesting because the earliest primary prevention of bone loss is the constitution of a satisfactory "bone capital" during the periods of childhood and adolescence.

Clinical screening for vitamin D deficiency in search of bone deformities should be carried out during vaccination reminders and consultations and the organization of continuing medical education in order to better train general practitioners and pediatricians, who are not very aware of this subject. Diagnosis of vitamin D deficiency should be evoked more easily by the medical profession, especially since confirmation of the diagnosis is easy and supplementation is simple, inexpensive and well tolerated.

Conflict of interest: none

\section{Bibliography}

1. Wahl DA, Cooper C, Ebeling R, et al. (2012) Vitamin D 
levels in healthy populations around the globe Archives of osteoporosis august. 1007-11657.

2. B Ship. (2006) News on the vitamin D 28th congress American Society for Bone and Mineral Research Philadelphia.

3. Holick MF. (2006) High prevalence of vitamin D inadequacy and implications for health. Mayo Clin Proc. 81(3): 353-373.

4. Bacchetta J, Ranchin B, Dubourg L, et al. (2010) Vitamin D: a major player in health? Arch Pediatr. 17: 16871695.

5. Djennane M. (2015) Vitamin D status and calcium intake of school children aged between 5-15 years in the locality of Tizi Ouzou. Thése DESM 2013. Batna J Med Sci. 2) 1: 7-12.

6. Ahmed SR. (1974) Study medicosocial of the infant of the baldia de chéraga. doctoral thesis in medicine Algiers.
7. Chouakri O. (1974) Study of the frequency of rickets in urban areas. doctoral thesis in medicine Algiers.

8. Holick M. (2005) Vitamin D: molecular biology, physiology, and clinical applications. Humana Press. The Vitamin D Epidemic nd its Health Consequences. a J. Nutr. 135(11): 2739S-2748.

9. Cranney S, Ann P. (2007) Effectiveness and safety of vitamin $\mathrm{D}$ in relation to bone health. Evidence Report/Technology Assessment. (158): 1-235.

10. Grote J. (2006) Vitamin D Deficiency. JAMA. 295: 1002 .

11. Vardon F. (2015) Development of the clinical tibiofemoral angle in normal adolescents. J Bone Joint Surg. 77(5): 729-735.

12. Plotnikoff GA, Quigley JM. (2003) Prevalence of severe hypovitaminosis $\mathrm{D}$ in patients with persistent, nonspecific musculoskeletal pain. Mayo Clin Proc. Dec.78(12): 1463-1470. 